\title{
Trade-off between photovoltaic systems installation and agricultural practices on arable lands: An environmental and socio-economic impact analysis for Italy
}

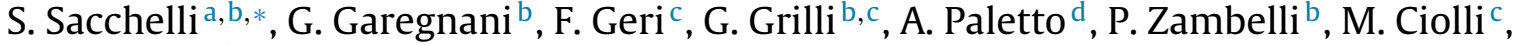 \\ D. Vettorato ${ }^{\text {b }}$ \\ a Department of Agricultural, Food and Forest Systems Management, University of Florence, P.le delle Cascine 18, 50144 Florence, Italy \\ ${ }^{\mathrm{b}}$ European Academy of Bolzano, Via G. Di Vittorio 16, 39100 Bolzano, Italy \\ ${ }^{\mathrm{c}}$ Department of Civil, Environmental and Mechanical Engineering, University of Trento, via Mesiano 77, 38123 Trento, Italy \\ d Council for Agricultural Research and Economics - Forest Monitoring and Planning Research Unit (CRA-MPF), P.za Nicolini 6, 38123, Villazzano, Trento, \\ Italy
}

\section{A R T I C L E I N F O}

\section{Article history:}

Received 13 October 2015

Received in revised form 1 April 2016

Accepted 24 April 2016

\section{Keywords:}

Solar energy

Spatial analysis

Open-source model

Sustainability constraint

Crop production

Trade-off evaluation

\begin{abstract}
A B S T R A C T
The paper introduces and discusses an open-source spatial-based model (called r.green.solar) able to quantify the energy production from solar photovoltaic (PV) ground-mounted panels. Socio-economic and environmental impacts can be evaluated by the model. The model starts from the theoretical quantity of solar PV potential energy and estimates a reduction of total amount of energy based on legal, technical, recommended and economic constraints. Model outputs were used for a trade-off analysis between energy production and traditional crops for food/feed cultivation on not irrigated arable land. The model was tested at regional level for a Mediterranean context (Italy). The results confirm that the economic profitability of PV systems follows a north-south gradient, but the main impacts are related to local peculiarities - such as the disposal of not irrigated arable land and the presence of constraints, in particular the landscape maintenance, the morphological variables and the specialization index - and crop yields.
\end{abstract}

(C) 2016 Elsevier Ltd. All rights reserved.

\section{Introduction}

In order to cope with negative effects of climate change, several political measures and actions have been applied worldwide in recent years. Normative rules have been particularly focused on the reduction of carbon dioxide emissions and substitution of fossil fuels with renewable energy (RE) sources. In this sense, the European Commission released the Directive 2009/28/EC on the promotion of the use of energy from renewable sources. This Directive - also known as 20-20-20 strategy - reports on mandatory national targets and measures for the use of energy from renewable sources, highlighting at the same time the need of national RE action plans. Despite to date several environmental and socio-economic benefits have been recognized to $\mathrm{RE}$, in the recent scientific literature a growing interest is given to the evaluation of potential negative impacts as well as integrated analysis (see e.g., Valodka

\footnotetext{
* Corresponding author at: Department of Agricultural, Food and Forest Systems Management, University of Florence, P.le delle Cascine 18, 50144 Florence, Italy.

E-mail address: sandro.sacchelli@unifi.it (S. Sacchelli).
}

and Valodkienè, 2015; Bilgili et al., 2016). Taking into account the Directive 2009/28/EC, sustainability criteria for RE production are strictly defined only for biofuels and bioliquids. However, also the other RE sources (i.e. geothermal, hydropower, wind and solar power) can affect a specific production and/or consumption areas in ecological, social and economic terms. Particularly, these RE sources can have significant impacts on certain Ecosystem Services (ESs). To cope with risk of negative impacts, a number of studies and models have been carried out, paying particular attention to biomass/biofuels production (see e.g. Verkerk et al., 2011; Dominik and Rainer, 2014; Upham and Smith, 2014), wind power (Kouloumpis et al., 2013; Yuan et al., 2015), hydropower (Daini, 2000; Chen et al., 2015) and solar energy (Kaygusuz, 2009; Wanderer and Herle, 2015).

One of the first studies focused on assessment of the potential impacts of solar energy was developed by Neff (1981). In that work, the author pointed out some important relationships between the implementation of photovoltaic (PV) technology and the consequences on public occupational safety and health. A particular emphasis was given to the indirect effects on labor market as well as to environmental consequences. In this sense, land use, 


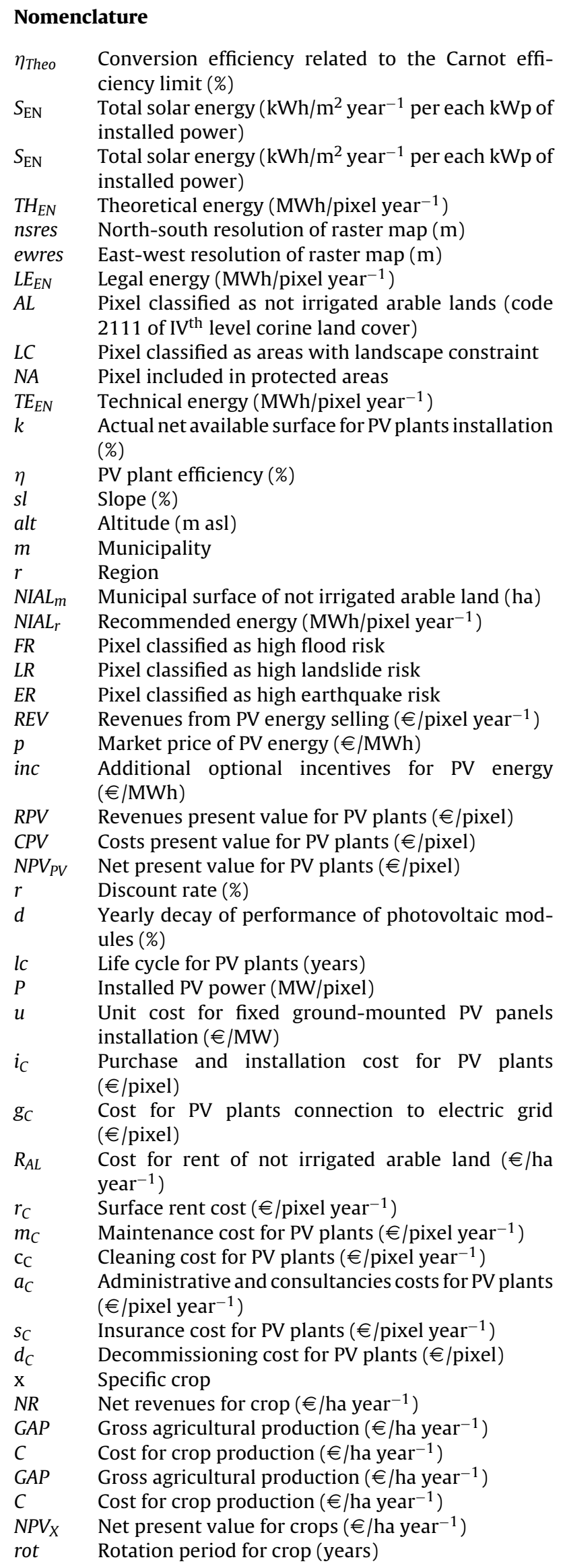

thermal and climatic effects and emissions were identified as relevant issues to be evaluated. A balance in positive and negative impacts of solar PV energy was defined in Swapnil Dubey et al. (2013), by a categorization of consequences in different classes: (i) land use and landscape, (ii) infrastructure, (iii) political, (iv) energy market, (v) industry, R\&D, education and (vi) public \& marketing. More insights about large-scale PV plants were given in Phillips (2013). The author depicted how the PV systems can be conducive to achieving a high level of sustainability, compared to traditional energy sources for both construction and operation phases. Detrimental effect could be revealed for few wildlife species (i.e. for flight hazards). Neutral impacts were defined for other features such as visual aesthetics, land occupation or habitat fragmentation. In addition, unknown effects were highlighted by the author, in particular related to soil and water impact as well as to local climatic variation (change in surface albedo and other surface energy flows). Life Cycle Assessment (LCA) approach - including disposal, and/or recycling phase of panels - is another applied methodology for PV impact appraisal (see e.g. Fthenakis and Chul Kim, 2009; Turconi et al., 2013; Dubey et al., 2013). A recent approach deals with the analysis of PV impact on ESs following the classification proposed by the Millennium Ecosystem Assessment (Hastik et al., 2015).

A literature review about territorial and landscape impacts for solar power plants was implemented by Chiabrando et al. (2009), with a real application for ground-mounted PV. Among different potential negative effects the authors introduced an in-depth assessment of glare risk due to panels. Zanon and Verones (2013) stressed the risk of PV conflicts on the use of fertile areas or the impact of technical equipment on the landscape. Public perception of PV systems was investigated by Tsantopoulos et al. (2014) in Greece with resulting environmentally-friendly, sustainable and socially acceptable opinions for this RE from citizens. Heras-Saizarbitoria et al. (2011) investigated the public acceptance of PV solar energy in Spain through the role played by the media. However, as shown in Brudermann et al. (2013), although some decision makers - such as farmers - usually have rather strong eco-attitudes and ethical considerations about PV systems implementation, these factors do not seem to be good predictors with respect to the adoption of PV technology.

An awkward problem concerning ground-mounted PV plants is often depicted in land use competition with crop production. Some studies showed the importance of site characteristics for trade-off analysis: for example, soil fertility or type of agricultural land (arable land, marginal land etc.) were considered with different degrees of suitability for PV energy production/crop cultivation (Nonhebel, 2005; Sliz-Szkliniarz, 2013; Calvert and Mabee, 2015). A PV energy vs. food trade-off was analyzed in Nonhebel (2005) stressing the yield importance of different locations. The evaluation of ground-based PV applications related to land quality were carried out in a GIS-based model of Sliz-Szkliniarz (2013). In a study by Calvert and Mabee (2015) market parameters - energy density as well as potential electricity production - were chosen as key elements to establish a trade-off analysis between solar energy and energy crops cultivation on marginal land in Ontario (Canada). Optimization techniques such as the agrivoltaic system, implemented by means of Land Equivalent Ratios, were applied to combine in a same area PV plants and agriculture production in order to maximize total energy efficiency (for both solar panel and crops) (Dupraz et al., 2011).

As outlined in the literature, a consistent number of scientific works concerning potential conflict between PV plants and agricultural production was depicted. Nevertheless, the examination of the above mentioned studies denotes the presence of a few flexible and updatable Decision Support Systems (DSS) suitable for analysis at different scale, in different contexts and with diverse input dataset available to decision makers. 


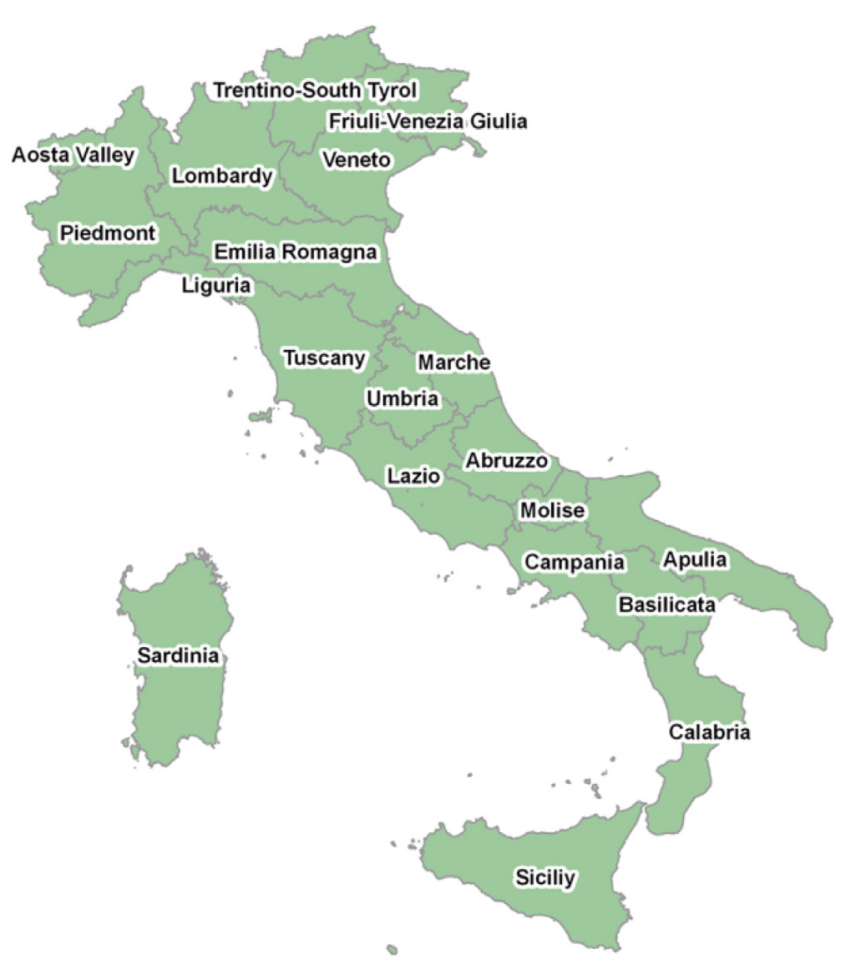

Fig. 1. Study area.

In this framework, the paper continues our previous works (Garegnani et al., 2015a) whose objective was to implement and test a new Geographic Information System (GIS) based model named r.green (http://www.recharge-green.eu/approach/ ). This model is carried out with a modular and multistep procedure that enables the quantification of energy from theoretical to economic. Reduction of energy availability can be taken into account through the evaluation of potential impacts on ESs. To date the r.green.biomassfor (Zambelli et al., 2012; Sacchelli et al., 2013; http:/grass.osgeo.org/grass70/manuals/ addons/r.green.biomassfor.html) and r.green.hydro (Garegnani et al., 2015b; http://grass.osgeo.org/grass70/manuals/addons/r. green.hydro.html) sub-models are available as add-ons for Quantum GIS and GRASS GIS software; these DSSs are focused on forest biomass for energy production and hydropower analysis, respectively. Specifically, the aim of this work was to develop and apply the r.green.solar sub-model focused on the quantification of sustainable energy from fixed ground-mounted photovoltaic (PV) panels, in order to make the DSS freely available in add-on repository of Quantum GIS and GRASS GIS softwares. The r.green.solar outputs were used to develop a trade-off analysis between traditional agricultural production and implemented PV plants on arable land by the integration of spatial analysis and economic indexes.

\section{Methodology}

Due to the fact that Mediterranean area is one of the most promising for solar energy availability in Europe, Italy was chosen as case study with a focus at a regional level (Fig. 1).

The work was developed in three phases. In the first phase the r.green.solar model was implemented as bash scripts able to quantify electric solar energy availability classified in:

- Theoretical;

- Legal;

- Technical;

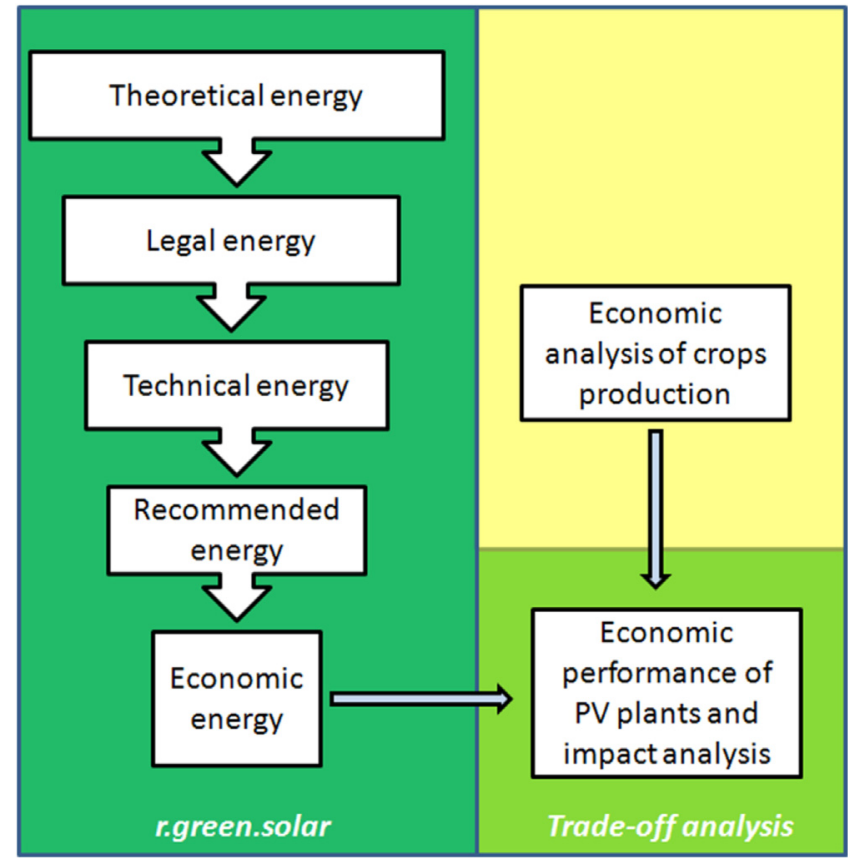

Fig. 2. General framework of the work.

- Recommended;

- Economic.

In the second phase the economic profitability of agricultural food and feed production on arable lands for each region, was analyzed. Eventually, performance of PV plant as well as trade-off and potential conflict among PV plants and traditional agricultural practices were estimated according to following indicators, as better explained in Section 2.2:

- Net Present Value for PV plants;

- Net Present Value for agricultural production;

- Internal Rate of Return for PV plants;

- Safety Margin of solar electric energy price;

- Potential crop losses in case of PV panels installation on arable lands.

The general framework of the work is reported in Fig. 2.

As a matter of fact the Directive 2009/28/EC was adopted by Italy in 2010, with a National Renewable Energy Action Plan (NREAP). According to the NREAP, the main support mechanism for electricity production from PV plants was the feed-in tariff mechanism (Conto Energia). This mechanism provides a sequential reduction up to 2013. Since 2013, PV incentives stopped and only tax deduction as well as facilitation for self-consumption have been maintained. However, despite the few possibilities to implement ground-mounted PV panels on arable land nowadays, a great number of PV plants have been realized. In other terms, developed impact analysis represents a spatial evaluation suitable for both implemented PV systems and potential future application.

\subsection{Implementation of r.green.solar model}

The GIS-based tool computes a multistep procedure to quantify solar PV energy, taking into account the legal, technical, recommended and economic constraints. The first step was dataset integration. The model automatically imports the variables (Table 1) and transforms them into a raster map (in case of shapefile format) with a specified pixel resolution. Numerical values related 
Table 1

Input dataset.

\begin{tabular}{ll}
\hline Variable & Variable typology \\
\hline Solar radiation & Raster \\
Digital Terrain Model (DTM) & Raster \\
Corine Land Cover map & Raster \\
Landscape constraints & Shapefile \\
Natural protected areas & Shapefile \\
Flood risk & Shapefile \\
Seismic risk & Shapefile \\
Landslide risk & Shapefile \\
Arable land specialization index & Shapefile \\
Roads & Shapefile \\
Regions boundary & Shapefile \\
\hline
\end{tabular}

to spatial-independent coefficients applied in the case study, were reported in Appendix A.

Theoretical energy derives from Photovoltaic Geographical Information System (PVGIS, www.re.jrc.ec.europa.eu/pvgis), a spatial-based assessment of solar electric energy resource from PV systems in Europe, Africa, and South-West Asia (Šúri et al., 2007; Huld et al., 2012). Those data are obtained from the application of r.sun module of GRASS GIS tool (see e.g. Nguyen and Pearce, 2010) and represent long-term yearly averages, based on satellite data retrieval for global irradiation on an optimally-inclined surface (period 1998-2011). Theoretical energy was computed by transformation of original data from PVGIS into equivalent energy per $i$-th pixel (expressed in MWh/year) taking into account the physical laws. In our case we set a squared pixel resolution equal to $100 \times 100 \mathrm{~m}$ (pixel surface of $1 \mathrm{ha}$ ). In fact, in Italy $30 \%$ of farms have an agricultural surface smaller than 1 ha (ISTAT, 2010). Field size has an influence on the accuracy of the applied methodology (Brown and Pervez, 2014). Therefore, to balance output detail and computational time of the model as well as to obtain an exhaustive representation of the factors analyzed with a reasonable amount of data processing (Romano et al., 2015), a pixel resolution of 1 ha was chosen.

Most solar cells on the market are based on silicon wafers and the upper theoretical was studied by Shockley and Queisser (1961). An optimal cell with a band gap of $1.3 \mathrm{eV}$ is limited by transmission losses of photons to $31 \%\left(310 \mathrm{~W}_{\mathrm{p}} \mathrm{m}^{-2}\right)$.

If we do not consider the current technology, according to thermodynamic laws, the conversion efficiency is related to the Carnot efficiency limit, which is nearly $95 \%$ (Green, 2002). Notice that the Carnot limit is only a theoretical limit and cannot be built in practice with technology currently available. This limit is then the uppermost value that it can be theoretically reached (Eq. (1)).

$T H_{E N i}=\eta_{\text {Theo }} \times S_{E N i} \times n$ sres $\times$ ewres $/ 1000$

Legal energy was depicted as the amount of theoretical energy available on exploitable surfaces from a normative point of view. According to these premises, suitable areas for PV plants implementation (in our case not irrigated arable land) were highlighted from Corine Land Cover Map (European Environment Agency, 2010); a limit of $10 \%$ of total available surface was applied based on Italian Legislative Decree 28/2011. Spatial constraints were then defined to depict inappropriate areas. A visual aesthetic limit was applied by the introduction of the national landscape constraints map (SITAP, 2015) as well as avoiding the insertion of PV panels in natural protected areas including national, regional and provincial parks, national and provincial reserves, natural protected areas of local interest as well as Natura 2000 network sites (National Cartographic Portal, 2015). It is worth mentioning how additional constraints could be defined in regional laws and regulations (e.g. constraints for PV systems implementation are depicted for Protected Designations of Origin and Protected Geographical
Indications territories). However, due to the lack of uniform data at regional level for Italy and to implement a precautionary evaluation of PV energy impact due to crop substitution, regional and sub-regional legal constraints were not introduced. Legal energy was defined as in Eq. (2).

$L E_{E N i}=T H_{E N i} \forall i \in(A L \& \neg L C \& \neg N A)$

Technical energy takes into account actual PV plants available surface, morphological characteristics and solar cell efficiency. In particular, shadow effect and space for maneuver were considered by depiction of a suitable percentage on total surface (Calvert and Mabee, 2015; Karaveli et al., 2015). Upper limits for terrain slope and altitude were defined to avoid improper areas for PV plant implementation (Bedin et al., 2011). Technical manuals and research outputs were finally evaluated to stress plants efficiency (see e.g Bedin et al., 2011; Miller and Lumby, 2012) (Eq. (3)).

$T E_{E N i}=L E_{E N i} \times k \times \eta \forall i \in(s l \leq 20 \&$ alt $\leq 800)$

In addition to the legal and technical limits, other constraints could be introduced, to reduce potential environmental and socioeconomic impacts due to PV plants installation. In fact, the model has the possibility to insert limits that can be included as optional maps, suggested by decision makers. Due to national characteristics, we introduced a hazard constraint on arable lands potentially subject to flood, landslide as well as earthquakes. These areas were considered unsuitable territories because of possible reduction of technical energy and damage of PV systems (National Cartographic Portal, 2015). Moreover, a Specialization Index (SI) related to arable lands was defined as an indicator of the weight that this land cover reaches at municipality level, with respect to a general context (Andini et al., 2013). In other words, SI is a particular value that is useful for detecting important local districts for a particular production in the agricultural, industrial or services sector, as well as for territorial characteristics. If the SI has a value greater than or equal to 2 it means that in the examined area there is a high specialization for the considered parameter (Fagarazzi et al., 2009). In our case study the $\mathrm{SI} \geq 2$ indicated a high importance of municipal not irrigated arable lands with respect to regional context and, as consequence, agricultural lands that should not be used for PV energy production (Eq. (4)).

$S I_{i}=\frac{N I A L_{m} / A A S_{m}}{N I A L_{r} / A A S_{r}} \forall i \in(m \& r)$

NIAL and AAS data derived from VI ${ }^{\text {th }}$ ISTAT Agricultural National Census (http://dati-censimentoagricoltura.istat.it/).

Thus, recommended energy taken into account all the above mentioned constraints (Eq. (5)):

$R E_{E N i}=T E_{E N i} \forall i \in(\neg F R \& \neg L R \& \neg E R \& \neg S I \geq 2)$

The final sub-model of r.green.solar computes the economic disposal of energy. In the first step, revenues from energy selling can be quantified as (Eq. (6)):

$R E V_{i}=R E_{E N i} \times(p+i n c)$

Actualised value of revenues can be computed as (Eq. (7)):

$R P V_{i}=R E V_{i} \times \frac{(1+r+d)^{l c}-1}{(r+d) \times(1+r+d)^{l c}}$

Implementation as well as operating and maintenance costs (O\&M) of PV plants include (Bedin et al., 2011): (i) purchase and installation, (ii) connection to electric grid, (iii) surface renting, (iv) maintenance, (v) cleaning, (vi) administrative and consultancies, (vii) insurance, (viii) decommissioning costs.

Purchase and installation costs are based on the installed power:

$i_{C i}=P_{i} \times u$ 
Table 2

Costs for connection to the electric grid.

\begin{tabular}{ll}
\hline Distance $(\mathrm{m})$ & Cost $(€)$ \\
\hline $\mathrm{D} \leq 200$ & 186 \\
$200<\mathrm{D} \leq 700$ & 279 \\
$700<\mathrm{D} \leq 1200$ & 836 \\
$\mathrm{D}>1200$ & 1950 \\
\hline
\end{tabular}

Table 3

Quantification of surface rent, maintenance, cleaning, administrative, consultancies and insurance costs.

\begin{tabular}{ll}
\hline Type of annual cost & Cost $(€)$ \\
\hline Surface rent & $r_{C i}=R_{A L} \times$ nsres $\times$ ewres $\forall i \in A L(9)$ \\
Maintenance & $m_{C}=i_{C i} \times 0.01(10)$ \\
Cleaning & $c_{C i}=$ if $\left(i_{C i} \times 0.001<\right.$ \\
& $1000)$ then 1000 else $\left(i_{C i} \times 0.001\right)(11)$ \\
Administrative and & $a_{C i}=$ if $\left(i_{C i} \times 0.001<\right.$ \\
consultancies & $3000)$ then 3000 else $\left(i_{C i} \times 0.001\right)(12)$ \\
Insurance & $s_{C i}=$ if $\left(i_{C i} \times 0.0015<\right.$ \\
& $2000)$ then 2000 else $\left(i_{C i} \times 0.0015\right)(13)$ \\
\hline
\end{tabular}

Costs for the connection to the grid are differentiated according to the distance. In the absence of a national dataset on geographic distribution of grid, a first approximation considered the distance from $i$-th pixel to roads (National Cartographic Portal, 2015). That costs vary according to Table 2 .

Surface rent costs for each land use are based on data from National Institute of Agricultural Economics (INEA, 2014). The other annual costs - point from (iv) to (vii) - were computed as a percentage of the installation costs (Table 3) (Bedin et al., 2011):

At the end of its life cycle, the plant must be dismantled, and the decommissioning costs must be taken into account (Eq. (14)).

$d_{C i}=i_{C i} \times 115$

Actualised costs can be expressed as (Eq. (15)):

$$
\begin{aligned}
C P V_{i}= & i_{C i}+g_{C i}+\left(r_{C i}+m_{C i}+c_{C i}+a_{C i}+s_{C i}\right) \\
& \times \frac{(1+r)^{l c}-1}{r \times(1+r)^{l c}}+\frac{d_{C i}}{(1+r)^{l c}}
\end{aligned}
$$

Eventually, the Net Present Value can be computed (Eq. (16)):

$N P V_{P V i}=R P V_{i}-C P V_{i}$

\subsection{Trade-off analysis}

The analysis of competition between PV panels and crops for food/feed was based on the selection of suitable plantations for each Italian region. The focus was on data from INEA (2013) that take into account economic analysis for the production of crops generally cultivated on non-irrigated arable lands (cereals and grain leguminous, industrial crops, forage crops ${ }^{1}$ ). For each production, the annual net revenues were computed as (Eq. (17)):

$N R_{x, r}=G A P_{x, r}-C_{x, r}$

Then, the net present value for crop cultivation was calculated based on a 4 years crop rotation period, on a total investment length equal to the PV panels lifecycle. In order to develop a precaution-

\footnotetext{
1 The examined crops are: oat, chickpea, spelt, broad bean, durum wheat, wheat, buckwheat, lentil, white lupin, millet, barley, garden pea, rye, aromatic and officinal herbs, rape-seed, sunflower, lavender, alfalfa, Perennial rye-grass, French grass, Spanish esparcet, Egyptian clover, Crimson clover, White clover, Red clover, common vetch.
}

ary evaluation for PV deployment, the more convenient crop (from economic point of view) was chosen for each region (Eq. (18)):

$N P V_{X r}=\operatorname{MAX}\left(N R_{x, r}\right) \times \frac{(1+r)^{l c}-1}{r \times(1+r)^{l c}}-\frac{\operatorname{MAX}\left(N R_{x, r}\right)}{(1+r)^{y}}$

where $y \in($ rot. $n, \ldots, l c)$ with $n=(1,2, \ldots, l c / r o t)$.

Once $\mathrm{NPV}_{\mathrm{PV}}$ and $\mathrm{NPV}_{\mathrm{X}}$ were compared, two economic indexes for PV energy production were quantified: internal rate of return (IRR) and safety margin (SM). The first gives an idea of the investment's profitability. In general, the IRR corresponds to the discount rate that makes the NPV equal to 0 (Eq. (19)). The latter represents the potential decrease of current energy price that maintain a convenience in renewable energy plants implementation in respect of crops cultivation (Eq. (20)):

$I R R_{i}=r \mid N P V_{P V i}=0$

$S M_{i}=p \mid N P V_{P V i, r}=N P V_{X, r}$

The final evaluations considered: (i) an analysis based on a percentage of economic surface that can be hypothetically used for PV energy production. For that areas, it was computed the amount of potential decline of crops due to PV plants implementation; (ii) a sensitivity analysis based on discount rate variation for computation of PV plants' economic efficiency.

\section{Results}

Table 4 shows potential available surfaces for PV implementation and energy from legal, technical, recommended and economic viewpoint. As matter of fact these variables assume a relevant importance for territorial planning; theoretical energy is synthetically reported in Fig. 4. A high potential for PV energy production is related to Sicily, Emilia Romagna, Lombardy, Veneto, Apulia and Sardinia. This denotes the disposal of a large amount of not irrigated arable lands (see legal energy).

A reduction of both energy and surface disposal is evident in case of introduction of technical constraints. The inclusion of technical and recommended constraints considerably reduced the energy potential of some regions in northern Italy. Specially, TrentinoSouth Tyrol and Liguria highlight a reduction of recommended energy up to $97.2 \%$ and $79.3 \%$ in comparison with legal energy, respectively. Higher decrease of recommended energy in southern regions is found for the following regions (Fig. 3): Calabria (60.9\%), Abruzzo (50.4\%), Campania (48.3\%), Sardinia (33.7\%), Molise (24.6\%) and Basilicata (24.5\%). In these regions the major limits are related to recommended constraints, in particular the earthquake risk and the SI (Fig. 4). Some of the central and northern regions - such as Emilia Romagna, Veneto, Lombardy and Piedmont - seem to be favorite by the low amount of surface with morphological (technical) constraints, i.e. slope and altitude (see Figs. 3 and 4). In these cases the reduction of energy availability from legal to recommended ranges from $0.3 \%$ to $1.2 \%$. In those regions it depends on the low weight of recommended constraints in respect to the legal and technical ones (in particular, as expressed by Fig. 4, a consistent overlap between the few area with recommended constraints and legal/technical limits is highlighted). Recommended and economic energies show the same results. This is due to the fact that neither current discount rate exceeds IRR nor price of energy is lower than safety margin. Therefore, the economic profitability of PV plants is always guaranteed.

$\mathrm{NPV}_{\mathrm{PV}}$ was computed as the average value of pixel with economic profitability for PV plants; the analysis was carried out by means of zonal statistic operations for each region (Fig. 5a). NPV derives from Eq. (18) (Fig. 5b).

Results denote a north-south gradient of convenience for PV plants. The average $\mathrm{NPV}_{\mathrm{PV}}$ ranges from $169,798 € /$ ha of Trentino- 
Table 4

Energy potential $\left(\mathrm{GWh} /\right.$ year $\left.\times 10^{-3}\right)$ and available surface (ha) per region.

\begin{tabular}{|c|c|c|c|c|c|c|c|c|}
\hline \multirow[t]{2}{*}{ Region } & \multicolumn{2}{|l|}{ Legal } & \multicolumn{2}{|c|}{ Technical } & \multicolumn{2}{|c|}{ Recommended } & \multicolumn{2}{|c|}{ Economic } \\
\hline & Energy & Surface & Energy & Surface & Energy & Surface & Energy & Surface \\
\hline Piedmont & 716.5 & 41,081 & 107.32 & 41,022 & 106.23 & 40,604 & 106.23 & 40,604 \\
\hline Aosta Valley & 0.0 & 0 & 0.00 & 0 & 0.00 & 0 & 0.00 & 0 \\
\hline Lombardy & 1382.1 & 80,724 & 206.70 & 80,455 & 206.69 & 80,451 & 206.69 & 80,451 \\
\hline Trentino-South Tyrol & 5.2 & 358 & 0.08 & 36 & 0.02 & 10 & 0.02 & 10 \\
\hline Veneto & $1,227.6$ & 71,915 & 183.98 & 71,850 & 183.14 & 71,525 & 183.14 & 71,525 \\
\hline Friuli-Venezia Giulia & 308.0 & 18,647 & 46.15 & 18,624 & 44.11 & 17,757 & 44.11 & 17,757 \\
\hline Liguria & 8.9 & 536 & 1.15 & 459 & 0.27 & 111 & 0.27 & 111 \\
\hline Emilia Romagna & 1480.9 & 86,463 & 221.14 & 86,066 & 220.89 & 85,967 & 220.89 & 85,967 \\
\hline Tuscany & 897.3 & 49,778 & 133.09 & 49,212 & 123.52 & 45,736 & 123.52 & 45,736 \\
\hline Umbria & 404.7 & 22,570 & 58.27 & 21,636 & 53.66 & 19,938 & 53.66 & 19,938 \\
\hline Marche & 647.8 & 37,674 & 91.07 & 35,279 & 85.53 & 33,140 & 85.53 & 33,140 \\
\hline Lazio & 847.9 & 44,839 & 123.97 & 43,620 & 119.39 & 41,952 & 119.39 & 41,952 \\
\hline Abruzzo & 146.0 & 8216 & 19.94 & 7471 & 10.94 & 4078 & 10.94 & 4078 \\
\hline Molise & 211.4 & 11,735 & 28.44 & 10,508 & 24.16 & 8850 & 24.16 & 8850 \\
\hline Campania & 377.5 & 20,509 & 53.72 & 19,412 & 30.14 & 10,611 & 30.14 & 10,611 \\
\hline Apulia & 1203.7 & 63,685 & 179.31 & 63,228 & 155.66 & 54,739 & 155.66 & 54,739 \\
\hline Basilicata & 555.8 & 30,057 & 75.06 & 26,954 & 63.76 & 22,701 & 63.76 & 22,701 \\
\hline Calabria & 352.2 & 18,299 & 45.41 & 15,584 & 20.96 & 7158 & 20.96 & 7158 \\
\hline Sicily & 1588.5 & 77,542 & 219.19 & 71,133 & 210.31 & 68,232 & 210.31 & 68,232 \\
\hline Sardinia & 1023.7 & 51,418 & 150.55 & 50,382 & 100.79 & 34,079 & 100.79 & 34,079 \\
\hline Total & $13,385.6$ & 736,047 & 1945 & 712,929 & 1760 & 647,637 & 1760 & 647,637 \\
\hline
\end{tabular}

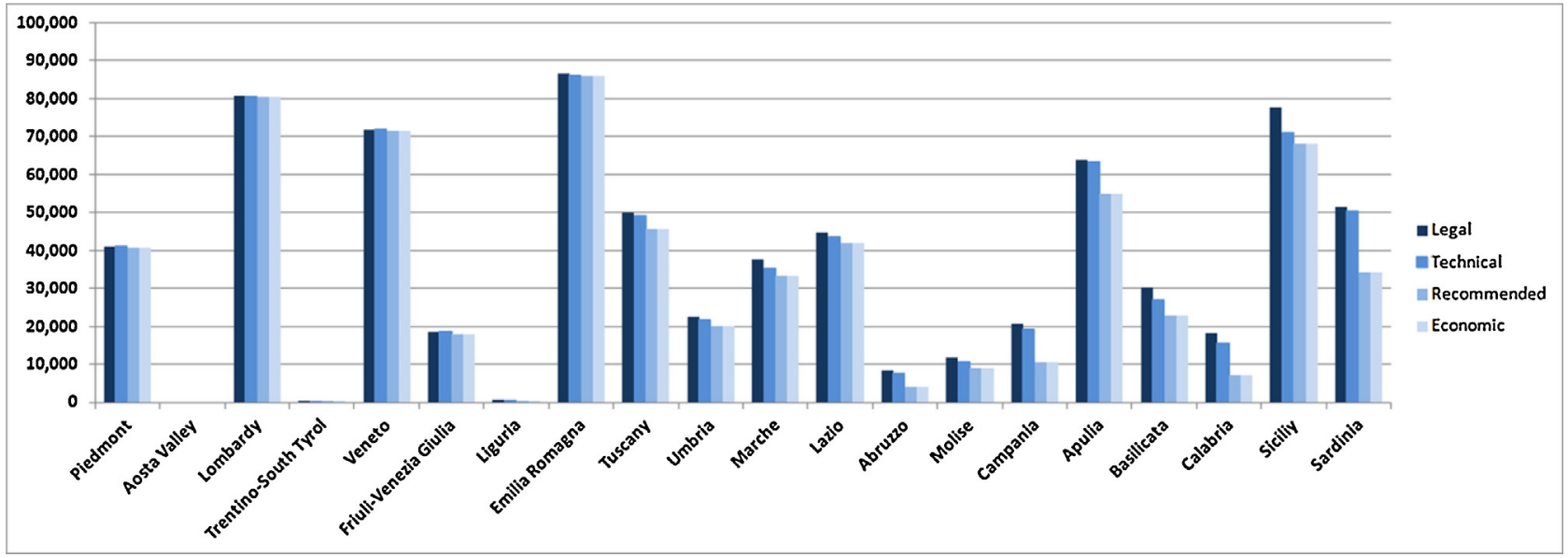

Fig. 3. Reduction of PV surface from legal to economic parameters for each Italian region (ha).

South Tyrol to $287,282 €$ /ha of Sicily taking into account a 20 -years PV systems life cycle and a discount rate of $3 \%$ (Fig. 5a).

A similar trend is denoted for both average IRR and SM (Fig. 6). IRR varies from 31\% (Trentino-South Tyrol) to 49\% (Sicily). SM ranges from $54 € / \mathrm{MWh}$ of Liguria to $69 € / \mathrm{MWh}$ of Sicily. A great profitability of PV investments is denoted by both indexes.

This aspect was also confirmed by the analysis of Fig. 5a and $b$, in which the difference between $N P V_{P V}$ and $N P V_{X}$ reaches an order of magnitude (range from $\mathrm{NPV}_{\mathrm{PV} \text {,Umbria }}=10 \times \mathrm{NPV}_{\mathrm{X}, \mathrm{Umbria}}$ to $\left.\mathrm{NPV}_{\mathrm{PV} \text {,Sicily }}=48 \times \mathrm{NPV}_{\mathrm{X}, \text { Sicily }}\right)$.

In this framework, it is interesting to evaluate the potential drop in crop production due to PV plants implementation. Three scenarios were carried out assuming $5 \%, 10 \%$ and $15 \%$ of economic surface use and real data concerning the crop yield (INEA, 2013). Results are reported in Table 5.

Basing on yield of crop that maximize $\mathrm{NPV}_{\mathrm{X}}$ for each region, results show how potential agricultural losses do not follow PV economic convenience. As matter of fact, relevant decreasing of crop production are depicted for region with a combination of high crop yield as well as availability of not irrigated arable lands (i.e. Emilia Romagna, Veneto, Lombardy and Piedmont).

A final remark regards the potential variability of technical as well as economic parameters and their impact on PV plants prof- itability. Available technology suggests how a strong increase in plants efficiency cannot be forecasted at short-medium term. On the other hand, is demonstrated that one of the most significant variable for economic efficiency is discount rate. Given this premise a sensitivity analysis for NPV $\mathrm{PV}$ computation, based on modification of discount rate, was developed (Cozzi et al., 2014). Results are expresses by Table 6 .

Table 6 highlights the importance of discount rate for $\mathrm{NPV}_{\mathrm{PV}}$ quantification as well as how its variation can bring to relevant instability of economic performance. Also in this case a northsouth gradient is revealed stressing a higher worsening of PV plants economic performance in northern regions, in case of augmented discount rate.

\section{Discussion and conclusions}

The developed model permits an evaluation of PV energy availability, based on modular and multistep analysis. Starting from the total solar energy disposal and the theoretical availability, different constraints can be included to reduce the harvestable quantities from legal, technical, recommended and economic point of view. The flexible approach allows the consideration of dif- 

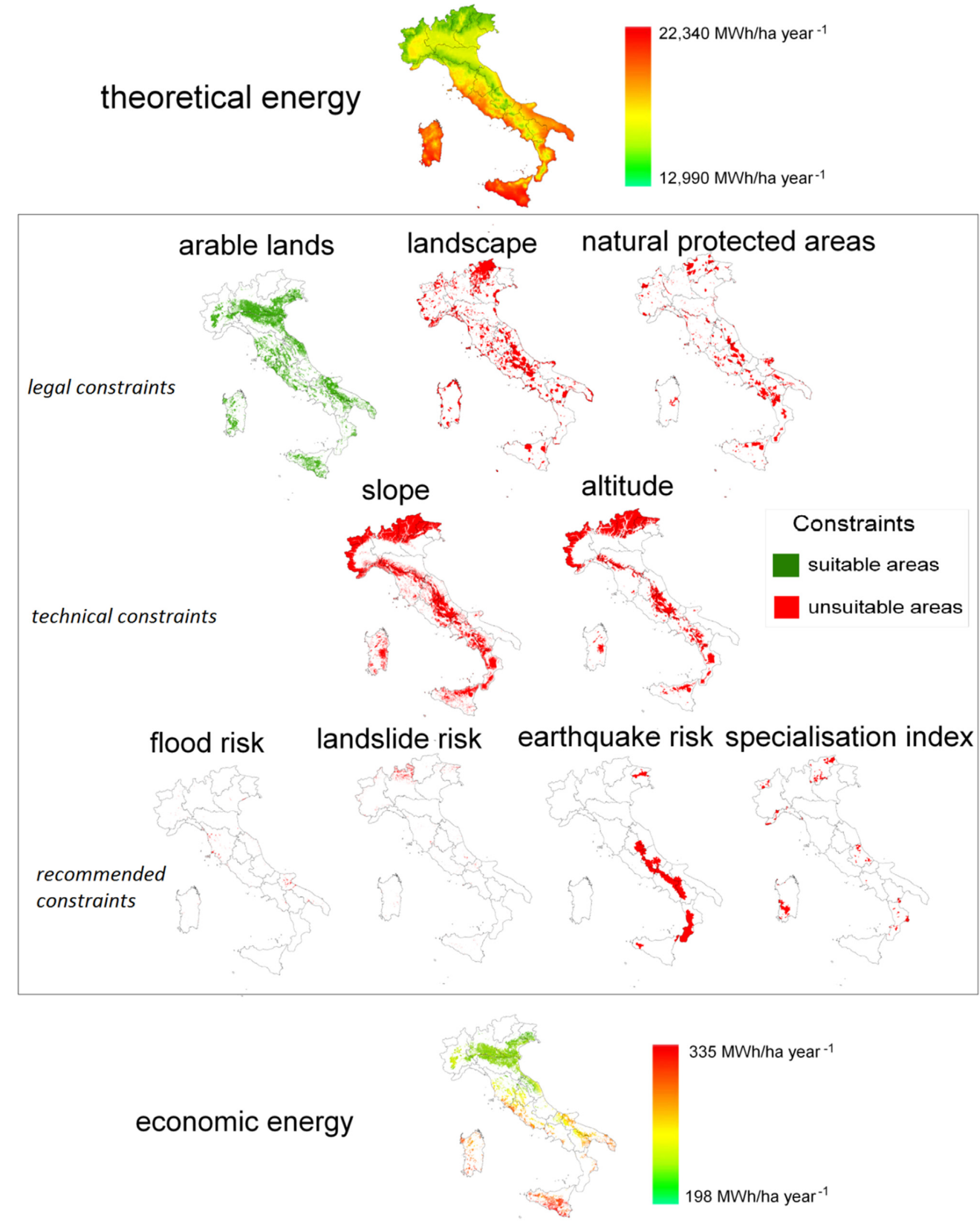

Fig. 4. Theoretical and economic energy; constraints applied for computation of legal, technical and recommended energy.

ferent input dataset and the modification of the constraints, as well as of variables facilitating applications in contexts with different characteristics and normative prescriptions. The raster-based method consents a multiscale analysis through various level of pixel aggregation (e.g. at municipal, regional or national level). Potential environmental and socio-economic impacts due to PV plants implementation can be considered and reduced by the definition of related constraints. 

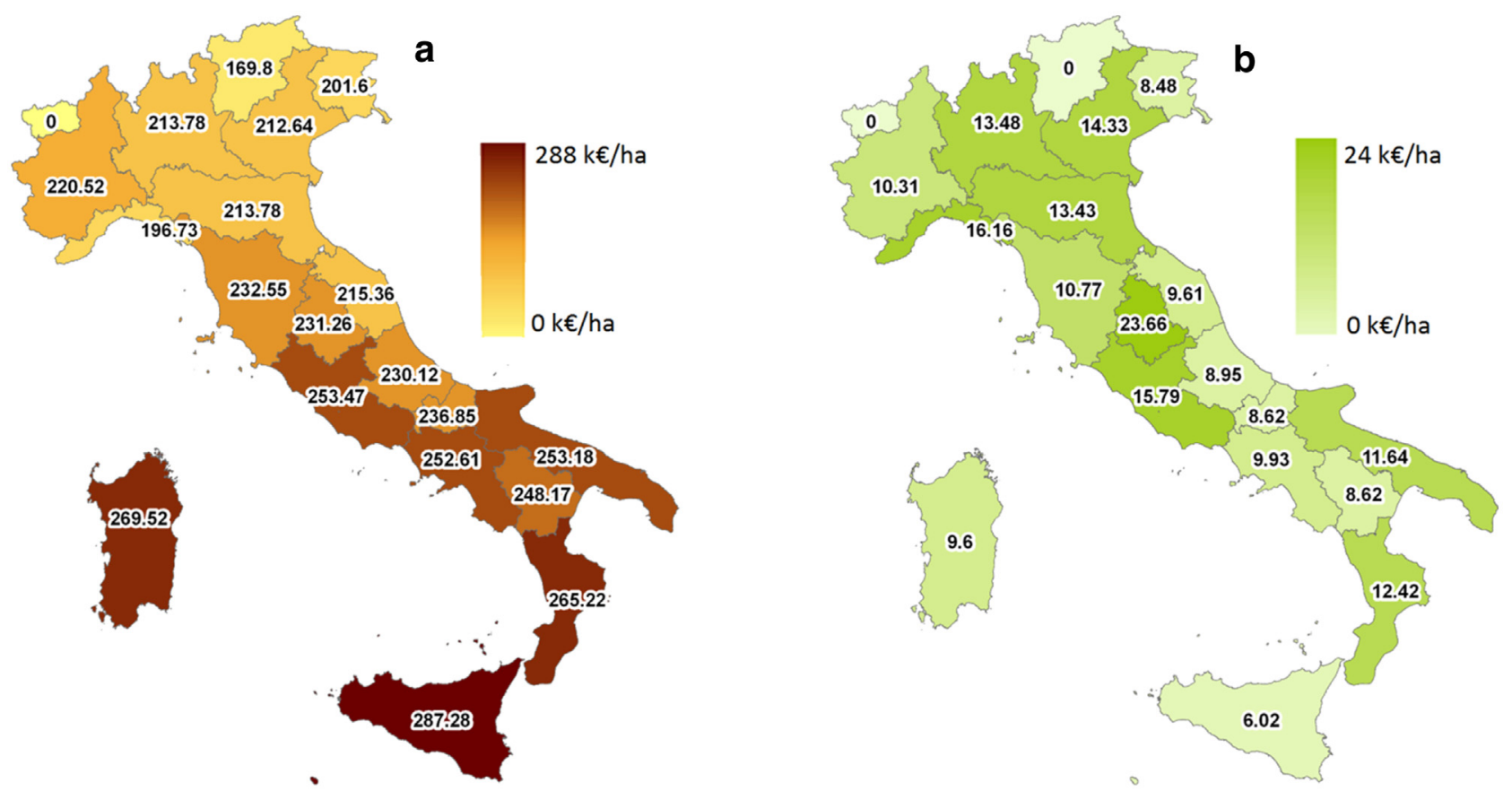

Fig. 5. (a) Average Net Present Value for PV plants - NPV $\mathrm{PV}(\mathrm{k} € /$ ha $)$; (b) Average Net Present Value for crop production - NPV $\mathrm{X}(\mathrm{k} € /$ ha $)$.

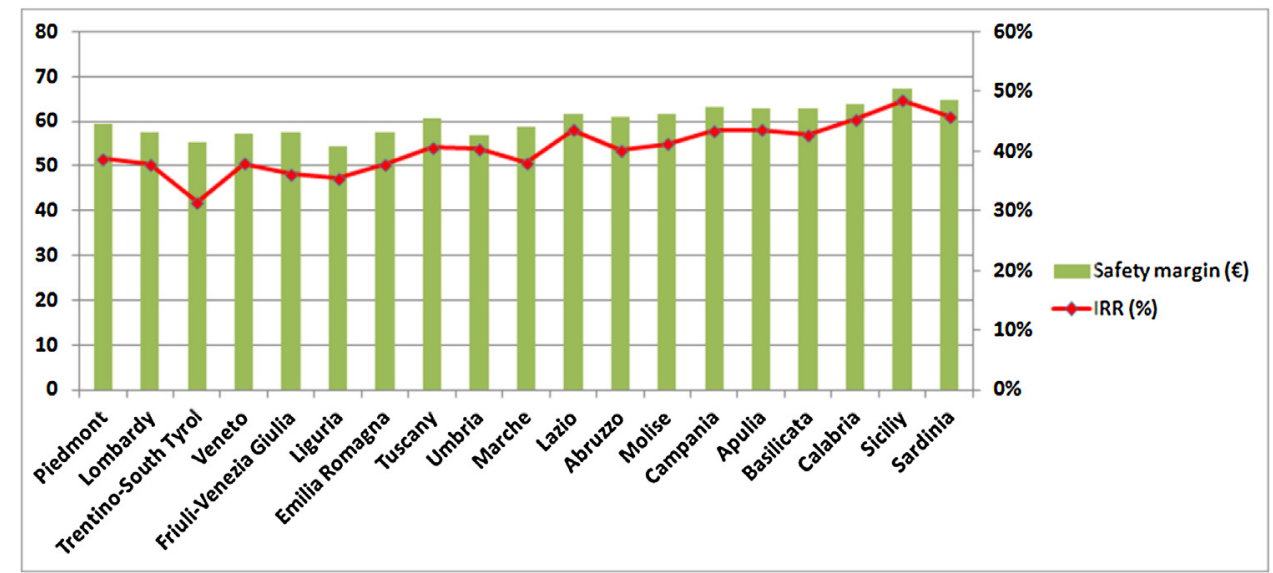

Fig. 6. Safety margin and Internal Rate of Return for PV plants.

Table 5

Example of potential crop losses in case of PV panels installation on arable lands.

\begin{tabular}{|c|c|c|c|c|c|}
\hline \multirow[t]{2}{*}{ Region } & \multirow[t]{2}{*}{ Surface (ha) } & \multirow[t]{2}{*}{ Crop yield (t/ha year ${ }^{-1}$ ) } & \multicolumn{3}{|c|}{ Potential crop losses (t/year) } \\
\hline & & & PV surface (5\%) & PV surface (10\%) & PV surface (15\%) \\
\hline Piedmont & 40,604 & 5.93 & 12,033 & 24,065 & 36,098 \\
\hline Aosta Valley & 0 & 0.00 & 0 & 0 & 0 \\
\hline Lombardy & 80,451 & 5.60 & 22,524 & 45,047 & 67,571 \\
\hline Trentino-South Tyrol & 10 & 0.00 & 0 & 0 & 0 \\
\hline Veneto & 71,525 & 9.87 & 35,307 & 70,614 & 105,921 \\
\hline Friuli-Venezia Giulia & 17,757 & 9.40 & 8343 & 16,686 & 25,029 \\
\hline Liguria & 111 & 9.68 & 54 & 107 & 161 \\
\hline Emilia Romagna & 85,967 & 9.75 & 41,927 & 83,853 & 125,780 \\
\hline Tuscany & 45,736 & 2.09 & 4772 & 9545 & 14,317 \\
\hline Umbria & 19,938 & 0.86 & 862 & 1724 & 2586 \\
\hline Marche & 33,140 & 4.53 & 7503 & 15,005 & 22,508 \\
\hline Lazio & 41,952 & 0.97 & 2042 & 4083 & 6125 \\
\hline Abruzzo & 4078 & 4.11 & 838 & 1675 & 2513 \\
\hline Molise & 8850 & 1.94 & 859 & 1718 & 2576 \\
\hline Campania & 10,611 & 11.16 & 5923 & 11,846 & 17,770 \\
\hline Apulia & 54,739 & 0.89 & 2439 & 4878 & 7317 \\
\hline Basilicata & 22,701 & 6.90 & 7836 & 15,672 & 23,508 \\
\hline Calabria & 7158 & 3.85 & 1378 & 2756 & 4134 \\
\hline Sicily & 68,232 & 1.84 & 6262 & 12,524 & 18,786 \\
\hline Sardinia & 34,079 & 2.95 & 5029 & 10,058 & 15,086 \\
\hline
\end{tabular}


Table 6

Sensitivity analysis based on discount rate.

\begin{tabular}{|c|c|c|c|c|c|c|c|c|c|c|}
\hline \multirow[b]{2}{*}{ Region } & \multicolumn{5}{|c|}{$\mathrm{NPV}_{\mathrm{PV}}(€ / \mathrm{ha})$} & \multicolumn{5}{|c|}{ reduction of $\mathrm{NPV}_{\mathrm{PV}}(\%)$} \\
\hline & $\mathrm{r}: 1 \%$ & $\mathrm{r}: 2 \%$ & $\mathrm{r}: 3 \%$ & r: $4 \%$ & r: $5 \%$ & "r" from $1 \%$ to $2 \%$ & "r" from $2 \%$ to $3 \%$ & "r" from $3 \%$ to $4 \%$ & "r" from $4 \%$ to $5 \%$ & "r" from $1 \%$ to $5 \%$ \\
\hline Piedmont & 267,892 & 239,796 & 220,517 & 193,593 & 174,543 & $-11.7 \%$ & $-8.7 \%$ & $-13.9 \%$ & $-10.9 \%$ & $-53.5 \%$ \\
\hline Lombardy & 259,780 & 232,419 & 213,783 & 187,421 & 168,867 & $-11.8 \%$ & $-8.7 \%$ & $-14.1 \%$ & $-11.0 \%$ & $-53.8 \%$ \\
\hline Trentino-South Tyrol & 206,751 & 184,177 & 169,798 & 147,024 & 131,693 & $-12.3 \%$ & $-8.5 \%$ & $-15.5 \%$ & $-11.6 \%$ & $-57.0 \%$ \\
\hline Veneto & 258,248 & 231,022 & 212,637 & 186,245 & 167,781 & $-11.8 \%$ & $-8.6 \%$ & $-14.2 \%$ & $-11.0 \%$ & $-53.9 \%$ \\
\hline Friuli-Venezia Giulia & 245,031 & 218,996 & 201,605 & 176,171 & 158,510 & $-11.9 \%$ & $-8.6 \%$ & $-14.4 \%$ & $-11.1 \%$ & $-54.6 \%$ \\
\hline Liguria & 239,182 & 213,687 & 196,734 & 171,747 & 154,449 & $-11.9 \%$ & $-8.6 \%$ & $-14.5 \%$ & $-11.2 \%$ & $-54.9 \%$ \\
\hline Emilia Romagna & 259,753 & 232,387 & 213,783 & 187,381 & 168,823 & $-11.8 \%$ & $-8.7 \%$ & $-14.1 \%$ & $-11.0 \%$ & $-53.9 \%$ \\
\hline Tuscany & 282,383 & 252,968 & 232,552 & 204,603 & 184,666 & $-11.6 \%$ & $-8.8 \%$ & $-13.7 \%$ & $-10.8 \%$ & $-52.9 \%$ \\
\hline Umbria & 280,736 & 251,469 & 231,262 & 203,348 & 183,511 & $-11.6 \%$ & $-8.7 \%$ & $-13.7 \%$ & $-10.8 \%$ & $-53.0 \%$ \\
\hline Marche & 261,703 & 234,158 & 215,359 & 188,860 & 170,183 & $-11.8 \%$ & $-8.7 \%$ & $-14.0 \%$ & $-11.0 \%$ & $-53.8 \%$ \\
\hline Lazio & 307,320 & 275,641 & 253,470 & 223,569 & 202,108 & $-11.5 \%$ & $-8.7 \%$ & $-13.4 \%$ & $-10.6 \%$ & $-52.1 \%$ \\
\hline Abruzzo & 279,626 & 250,477 & 230,116 & 202,550 & 182,792 & $-11.6 \%$ & $-8.8 \%$ & $-13.6 \%$ & $-10.8 \%$ & $-53.0 \%$ \\
\hline Molise & 287,242 & 257,369 & 236,850 & 208,255 & 188,009 & $-11.6 \%$ & $-8.7 \%$ & $-13.7 \%$ & $-10.8 \%$ & $-52.8 \%$ \\
\hline Campania & 306,588 & 275,001 & 252,610 & 223,078 & 201,679 & $-11.5 \%$ & $-8.9 \%$ & $-13.2 \%$ & $-10.6 \%$ & $-52.0 \%$ \\
\hline Apulia & 306,989 & 275,346 & 253,183 & 223,332 & 201,895 & $-11.5 \%$ & $-8.8 \%$ & $-13.4 \%$ & $-10.6 \%$ & $-52.1 \%$ \\
\hline Basilicata & 300,845 & 269,746 & 248,169 & 218,623 & 197,552 & $-11.5 \%$ & $-8.7 \%$ & $-13.5 \%$ & $-10.7 \%$ & $-52.3 \%$ \\
\hline Calabria & 321,445 & 288,487 & 265,218 & 234,317 & 211,995 & $-11.4 \%$ & $-8.8 \%$ & $-13.2 \%$ & $-10.5 \%$ & $-51.6 \%$ \\
\hline Sicily & 348,132 & 312,768 & 287,282 & 254,657 & 230,714 & $-11.3 \%$ & $-8.9 \%$ & $-12.8 \%$ & $-10.4 \%$ & $-50.9 \%$ \\
\hline Sardinia & 326,621 & 293,204 & 269,516 & 238,283 & 215,652 & $-11.4 \%$ & $-8.8 \%$ & $-13.1 \%$ & $-10.5 \%$ & $-51.5 \%$ \\
\hline
\end{tabular}

In this work, the r.green.solar model was applied to define energy potential from ground-mounted PV system, hypothetically inserted on not irrigated arable land. In fact, one of the aims of the research was to depict a trade-off between PV energy and crop for food/feed production. In future analyses, an extension to other land use could be easily carried out with the modification of a few input data. A potential application of the model to other European and global regions is also facilitated by modular composition and a wide availability of input data. In this case, a particular attention as to be paid to different legal constraints that can be in force in other Countries as well as to different input economic variables. Recommended constraints could also be modified basing on participative approaches and focus group involving local expert and stakeholders.

Although an higher disposal of solar energy per unit of surface is shown in southern regions of Italy, total amount of PV energy is strongly influenced by two main parameters: (i) the availability of not irrigated arable land and (ii) the presence of constraints, related to the landscape maintenance, morphological variables (slope and altitude), the earthquake risk and the specialization index. These features, linked to crop yield, lead to a greater potential impact - in terms of crops substitution - in northern region of Italy respect to central and southern ones, unless a north-south increasing gradient is shown for economic profitability. In fact, average Net Present Value, Internal Rate of Return and Safety Margin on electric energy price stress a strong convenience for PV plants investments in region such as Sicily, Sardinia and Calabria. With these premises, the model could represent a useful DSS for policy makers and local stakeholders, to quantify and communicate strengths as well as weaknesses of PV plants in a spatial-based manner.

Nevertheless, the application of r.green.solar for a local scale planning must consider additional analysis and data. For example, further constraints should be evaluated in case of geographic peculiarities (e.g. the presence of Protected Designations of Origin and Protected Geographical Indications territories as well as areas with a high specialization index for crops cultivated on arable land). An in-depth analysis of regulation could be also developed in order to consider provincial and regional variability as well as temporal dynamics of rules and incentives. Additional applications could go beyond the Boolean structure of constraints by the introduction of weighted value, e.g. in the form of Multi Criteria Analysis.

Trade-off analysis can be improved taking into account the geographical suitability for each cultivation and rotation among different crops. This aspect was here simplified by the comparison of PV energy production with the more profitable regional crops, to carry out a precautionary analysis.

Eventually, additional future insights could focus on the implementation of different scenarios and sub-models. The evaluation of the economic performance for different technologies (e.g. fixed vs single/dual axis trackers ground-mounted PV systems) or the quantification of impact on ESs (e.g. avoided $\mathrm{CO}_{2}$ emission in respect to fossil fuel and the impact on ecological corridors) could be developed to improve the study and better highlight the existing trade-offs.

\section{Acknowledgments}

This study was conducted in the frame of the recharge.green project "Balancing Alpine Energy and Nature" (http://www. recharge-green.eu), which is carried out within the Alpine Space Programme, and is co-financed by the European Regional Development Fund. Authors wish to acknowledge Recharge.Green project partners, for their contribution to the research.

\section{Appendix A.}

see Table A1.

Table A1

Quantification of parameters used in the case study (spatial-independent variables).

\begin{tabular}{lll}
\hline \multicolumn{2}{l}{ Symbol Description } & Value \\
\hline$\eta_{\text {Theo }}$ & Conversion efficiency related to the Carnot efficiency limit (\%) & 95 \\
$n s r e s$ & North-south resolution of raster map (m) & 100 \\
ewres & East-west resolution of raster map (m) & 100 \\
$k$ & Actual net available surface for PV plants installation (\%) & 20 \\
$\eta$ & PV plant efficiency (\%) & 75 \\
$p$ & Price of PV energy ( $€ /$ MWh) & 105.80 \\
$i n c$ & Additional optional incentives for PV energy (€/MWh) & 0 \\
$r$ & Dscount rate (\%) & 3 \\
$d$ & Yearly decay of performance of photovoltaic modules (\%) & 1 \\
$l c$ & Iife cycle for PV plants (years) & 20 \\
$P$ & Installed PV power (MW/pixel) & 0.2 \\
$u$ & Unit cost for fixed ground-mounted PV panels installation & 2500 \\
& $(€ / \mathrm{kW})$ & 800 \\
$R_{A L}$ & Cost for rent of not irrigated arable land (€/ha year ${ }^{-1}$ ) & \\
\hline
\end{tabular}


References

Šúri, M., Huld, T.A., Dunlop, E.D., Ossenbrink, H.A., 2007. Potential of solar electricity generation in the European Union member states and candidate countries. Sol. Energy 81, 1295-1305.

Andini, M., de Blasio, G., Duranton, G., Strange, W.C., 2013. Marshallian labour market pooling: evidence from Italy. Reg. Sci. Urban Econ. 43 (6), 1008-1022.

Bedin, D., Holland, E., Chies, A., Annunziata, V., Virdis, A., 2011. PVS in BLOOM Business Guide - Ground Photovoltaic Investments on Marginal Areas. Intelligent Energy Europe Programme (accessed 12.06.15) http://www. pvsinbloom.eu/.

Bilgili, F., Koçak, E., Bulut, Ü., 2016. The dynamic impact of renewable energy consumption on CO2 emissions: a revisited Environmental Kuznets Curve approach. Renew. Sust. Energ. Rev. 54, 838-845.

Brown, J.F., Pervez, M.S., 2014. Merging remote sensing data and national agricultural statistics to model change in irrigated agriculture. Agr. Syst. 127, $28-40$

Brudermann, T., Reinsberger, K., Orthofer, A., Kislinger, M., Posch, A., 2013. Photovoltaics in agriculture: a case study on decision making of farmers. Energy Policy 61, 96-103.

Calvert, K., Mabee, W., 2015. More solar farms or more bioenergy crops? Mapping and assessing potential land-use conflicts among renewable energy technologies in eastern Ontario, Canada. Appl. Geogr. 56, 209-221.

Chen, S., Chen, B., Fath, B.D., 2015. Assessing the cumulative environmental impact of hydropower construction on river systems based on energy network model. Renew. Sust. Energ. Rev. 42, 78-92.

Chiabrando, R., Fabrizio, E., Garnero, G., 2009. The territorial and landscape impacts of photovoltaic systems: definition of impacts and assessment of the glare risk. Renew. Sust. Energ. Rev. 13, 2441-2451.

Cozzi, M., Di Napoli, F., Viccaro, M., Fagarazzi, C., Romano, S., 2014. Ordered weight averaging multicriteria procedure and cost-effectiveness analysis for short rotation forestry in the Basilicata Region, Italy. Int. J. Global Energy 37, 282-303.

Daini, P., 2000. Environmental impact assessment for hydroelectric power plants in Trentino (Italy) 1990-1997: similarity and clustering of studies, sites and projects. IAPA 18 (1), 43-60.

Dominik, R., Rainer, J. (Eds.), 2014. Socio-Economic Impacts of Bioenergy Production. Springer.

Dubey, S., Jadhav, N.Y., Zakirova, B., 2013. Socio-economic and environmental impacts of silicon based photovoltaic (PV) technologies. Energy Procedia 33 322-334.

Dupraz, C., Marrou, H., Talbot, G., Dufour, L., Nogier, A., Ferard, Y., 2011. Combining solar photovoltaic panels and food crops for optimising land use: towards new agrivoltaic schemes. Renew. Energ. 36, 2725-2732.

European Environment Agency, 2010. Corine Land Cover 2006 Raster Data (accessed 12.06.15) http://www.eea.europa.eu/data-and-maps/data/corineland-cover-2006-raster.

Fagarazzi, C., Sacchelli, S., Chiaramonti, D., Prussi, M., Recchia, L., 2009. Socio-economic and environmental aspect related to development of agro-energetic chain: the case of Tuscany region. In: Proceedings of 17th European Biomass Conference and Exhibition, Hamburg, pp. 330-340.

Fthenakis, V., Chul Kim, H., 2009. Land use and electricity generation: a life-cycle analysis. Renew. Sust. Energ. Rev. 13, 1465-1474.

Garegnani, G., Geri, F., Zambelli, P., Grilli, G., Sacchelli, S., Paletto, A., Curetti, G., Ciolli, M. Vettorato, D., 2015a. A new open source DSS for assessment and planning of renewable energy: r.green. In: Proceedings of FOSS4G Europe, Como 2015, 14-17 June 2015, pp. 39-50.

Garegnani, G., Zambelli, P., Curetti, G., Grilli, G., Biscaini, S., Sacchelli, S., Geri, F., Ciolli, M., Vettorato, D., 2015b. A decision support system for hydropower production in the Gesso e Vermenagna valleys. In: E-proceedings of the 36th IAHR World Congress, The Hague, the Netherlands.

Green, M.A., 2002. Third generation photovoltaics: solar cells for 2020 and beyond. Physica E 14 (1-2), 65-70.

Hastik, R., Basso, S., Geitner, C., Haida, C., Poljanec, A., Portaccio, A., Vrščaj, B., Walzer, C., 2015. Renewable energies and ecosystem service impacts. Renew. Sust. Energ. Rev. 48, 608-623.

Heras-Saizarbitoria, I., Cilleruelob, E., Zamanillo, I., 2011. Public acceptance of renewables and the media: an analysis of the Spanish PV solar experience. Renew. Sust. Energ. Rev. 15 (9), 4685-4696.
Huld, T., Müller, R., Gambardella, A., 2012. A new solar radiation database for estimating PV performance in Europe and Africa. Sol. Energy 86, 1803-1815. INEA, 2013. Analisi Dei Risultati Economici Aziendali-RICA-INEA (accessed 12.06.15) http://www.rica.inea.it/public/it/area.php.

INEA, 2014. Banca Dati Dei Valori Fondiari-INEA (accessed 12.06.15) www.inea.it:8080/mercato-fondiario/banca-dati.

ISTAT, 2010. Sixth General Census of Agriculture 2010 (accessed 12.06.15) http:// dati-censimentoagricoltura.istat.it/Index.aspx.

Karaveli, A.B., Soytas, U., Akinoglu, B.G., 2015. Comparison of large scale solar PV (photovoltaic) and nuclear power plant investments in an emerging market. Energy 84, 656-665.

Kaygusuz, K., 2009. Environmental impacts of the solar energy systems. Energy Sources Part A 31 (15), 1376-1386.

Kouloumpis, V., Liu, X., Lees, E., 2013. Environmental impacts of renewable energy: gone with the wind? renewable energy governance. Lect. Notes Energy 23, 203-215.

Miller, A., Lumby, B., 2012. Utility Scale Solar Power Plants-A Guide For Developers and Investors. International Finance Corporation (IFC), Global Environment Facility (GEF), Austrian Ministry of Finance (accessed 12.06.15) www. ifc. org/hb-solarpowerplants.

National Cartographic Portal, 2015. Progetto Natura (accessed 12.06.15) http:/ www.pcn.minambiente.it/GN/.

Neff, T.L., 1981. The social cost of solar energy. In: A Study of Photovoltaic Energy Systems. Pergamon, New York.

Nguyen, H.T., Pearce, J.M., 2010. Estimating potential photovoltaic yield with r.sun and the open source Geographical Resources Analysis Support System. Sol. Energy 84, 831-843.

Nonhebel, S., 2005. Renewable energy and food supply: will there be enough land? Renew. Sust. Energ. Rev. 9, 191-201.

Phillips, J., 2013. Determining the sustainability of large-scale photovoltaic solar power plants. Renew. Sust. Energ. Rev. 27, 435-444.

Romano, G., Dal Sasso, P., Trisorio Liuzzi, G., Gentile, F., 2015. Multi-criteria decision analysis for land suitability mapping in a rural area of Southern Italy. Land Use Policy 48, 131-143.

SITAP, 2015. Landscape Constraint Map Ministry of Cultural Heritage and Activities and Tourism (accessed 12.06.15) http://www.sitap.beniculturali.it/.

Sacchelli, S., Zambelli, P., Zatelli, P., Ciolli, M., 2013. Biomasfor-an open-source holistic model for the assessment of sustainable forest bioenergy. iForest 6 285-293.

Shockley, W., Queisser, H.J., 1961. Detailed balance limit of efficiency of pn junction solar cells. J. Appl. Phys. 32 (3), 510-519.

Sliz-Szkliniarz, V.B., 2013. Assessment of the renewable energy-mix and land use trade-off at a regional level: a case study for the Kujawsko-Pomorskie. Land Use Policy 35, 257-270

Tsantopoulos, G., Arabatzis, G., Tampakis, S., 2014. Public attitudes towards photovoltaic developments: case study from Greece. Energ. Policy 71, 94-106.

Turconi, R., Boldrin, A., Astrup, T., 2013. Life cycle assessment (LCA) of electricity generation technologies: overview, comparability and limitations. Renew. Sust. Energ. Rev. 28, 555-565.

Upham, P., Smith, B., 2014. Using the Rapid Impact Assessment Matrix to synthesize biofuel and bioenergy impact assessment results: the example of medium scale bioenergy heat options. J. Clean. Prod. 65, 261-269.

Valodka, I., Valodkiené, G., 2015. The impact of renewable energy on the economy of Lithuania. Procedia 213, 123-128.

Verkerk, P.J., Anttila, P., Eggers, J., Lindner, M., Asikainen, A., 2011. The realisable potential supply of wood biomass from forests in the European Union. Forest Ecol. Manag. 261, 2007-2015.

Wanderer, T., Herle, S., 2015. Creating a spatial multi-criteria decision support system for energy related integrated environmental impact assessment. Environ. Impact Assess. 52, 2-8.

Yuan, X., Zuo, J., Huisingh, D., 2015. Social acceptance of wind power: a case study of Shandong Province, China. J. Clean. Prod. 92, 168-178.

Zambelli, P., Lora, C., Spinelli, R., Tattoni, C., Vitti, A., Zatelli, P., Ciolli, M., 2012. A GIS decision support system for regional forest management to assess biomass availability for renewable energy production. Environ. Modell. Softw. 38, 203-213.

Zanon, B., Verones, S., 2013. Climate change, urban energy and planning practices: italian experiences of innovation in land management tools. Land Use Policy 32, 343-355. 